\title{
THE WAVE OF '68. PORTRAITS OF REBEL STUDENTS IN THE ITALIAN PRESS
}

\author{
La ola del 68. Retratos de estudiantes rebeldes en la prensa italiana
}

\author{
Antonella Cagnolati \\ antonella.cagnolati@unifg.it \\ Università di Foggia. Italia
}

Date of reception: $17 / 02 / 2021$

Date accepted: $24 / 04 / 2021$

\begin{abstract}
This paper investigates the representation of university students in the collective Italian imaginary during '68 through the contemporary articles published in La Stampa and Stampa Sera describing the student uprisings at the University of Turin (Italy). The paper draws on a large amount of articles published in the daily newspapers La Stampa and Stampa Sera (nearly 400, from January to June 1968, the most dynamic phase of the protests) to highlight how journalists constructed the narrative of the rebellion by criticising the image of the rebel students, using words loaded with negative meanings and delegitimising their claims without any effort to understand their motivations. The image of the students that emerges from the articles over the period of time considered is negative, constructed to underline the destructive nature of the demonstrations against the political and social system of Italy in the 1960s. There was an unfailing tendency to highlight the rioting, disturbance of lessons, and physical and verbal attacks against teachers and the police, and the language used were reminiscent of that employed in times of war. The daily national press of the time is a rich source of material, with considerable interpretative and explanatory potential; in reconstructing the events day by day, it enables us to conduct an in-depth investigation into the ideology and the imaginary at play in a given space and time. It explores corners of the history of education that escape official recording and reveals the focus of interest and the priorities of the media groups.
\end{abstract}

Keywords: daily newspapers; 1968; public opinion; universities; Italy; La Stampa; Stampa Sera; student protests. 
Resumen: Este trabajo investiga la representación de los estudiantes universitarios en el imaginario colectivo italiano durante el 68 a través de los artículos contemporáneos publicados en La Stampa y Stampa Sera que describen los levantamientos estudiantiles de la Universidad de Turín (Italia). El periódico se basa en una gran cantidad de artículos publicados en los diarios La Stampa y Stampa Sera (cerca de 400, de enero a junio de 1968, la fase más dinámica de las protestas) para resaltar cómo los periodistas construyeron la narrativa de la rebelión criticando a la imagen de los estudiantes rebeldes, utilizando palabras cargadas de significados negativos y deslegitimando sus afirmaciones sin ningún esfuerzo por comprender sus motivaciones. La imagen de los estudiantes que surge de los artículos durante el período de tiempo considerado es negativa, construida para subrayar el carácter destructivo de las manifestaciones contra el sistema político y social de Italia en los años sesenta. Hubo una tendencia constante a destacar los disturbios, la alteración de las lecciones y los ataques físicos y verbales contra los maestros y la policía, y el lenguaje utilizado recordaba al empleado en tiempos de guerra. La prensa diaria nacional de la época es una rica fuente de material, con un considerable potencial interpretativo y explicativo; al reconstruir los acontecimientos día a día, nos permite realizar una investigación en profundidad sobre la ideología y el imaginario en juego en un espacio y un tiempo determinados. Explora rincones de la historia de la educación que escapan al registro oficial, y revela el foco de interés y las prioridades de los grupos mediáticos.

Palabras clave: diarios; 1968; opinión pública; universidades; Italia; La Stampa; Stampa Sera; protestas estudiantiles.

SUMMARY: 1. '68: a turning point. 2. Students: a new social subject. 3. Between facts and opinions. 4. The revolt in the articles of La Stampa and Stampa Sera: an analysis of trends. 5. Concluding reflections. 6. Bibliography. 6.1. Articles. 6.2. References.

\section{1. '68: A TURNING POINT}

The social unrest that swept across much of the world in the 1960s reached the shores of Italy in 1968, culminating in a series of mass demonstrations and university occupations. The research reports the preliminary findings of a wider study into the collective image of these student protests, created by the mass media fuelling the public consciousness. These historic events played a key role in both the construction of the specific icon of student as rebel, and the demonization of youth in general. Indeed, after this time young people were viewed with suspicion by a large part of Italian society, which remained conformist and strictly moralistic. At the same time, the students' easy adoption of myths and rites arriving from the United States, not to mention the trends, music, fashion and drugs that accompanied the largely Anglo-Saxon pop culture spreading across Italy, also made them a target for the "occult persuaders» seeking to exploit their consumer power (Packard, 1957).

Rather than merely analysing the political and ideological issues at play, this research is focused on the relationship between the students as a new social subject 
that suddenly appeared on the Italian scene and the narration produced by the mass media of the time, i.e., the press. In the late Sixties, the Italian press was strongly influenced by traditional middle-class values and had no interest whatsoever in trying to understand the real motivations behind the protests, effectively ganging up against the younger generations and adopting an increasingly crude and violent tone in the attempt to discredit them.

More than fifty years on, the jury is still out on '68, which remains a problematic and highly controversial issue. It is important to ask whether, in line with Gitlin's hypothesis, it was a moment of collective self-consciousness in which a generation was allowed to vent the repressed feelings that they would not otherwise have had the opportunity to express in the hierarchical and broadly conformist society of the time (Gitlin, 1987). Alternatively, as Touraine argues, we could develop a different theoretical analysis to place this event in a genealogical chain whose direct ascendants can be found in the socialist utopias of the $19^{\text {th }}$ century (Touraine, 1968).

The answer seems to differ according to the position in which the actors in the events, whether protagonists or mere secondary characters, found themselves at their culmination (late 1967, first half of 1968); some allowed emotion to cloud their memory, biasing them towards an overly positive assessment, albeit understandable as they experienced first-hand both an awakening of consciousness, and the collective dimension of life and shared struggle that involved them totally (Viale, 1978). Those who opposed this chain of events from its advent, on the other hand, consider it a veritable nightmare that it would be wise to wake up from-a kind of general madness that has undermined the foundations of society and given dignity of speech and relevance to the masses, who should have remained subdued, silent and marginalised, well away from the public and political stage (Ross, 2002).

That being said, however we consider it, ' 68 was a critical insurrection that allowed multitudes to cross the line between theory and practice, from egocentric individual goals to a collective, international Third-Worldist scenario, in an attempt to link the problems that individuals were facing with motivations explained by macroscopic phenomena of planetary dimensions (Marwick, 1998, 2005; Kurlansky, 2004; Artières and Zancarini-Fournel, 2008; Carey, 2016). If, from a shared sense of everyday life we then move on to the historiographic debate, we cannot fail to highlight how journalistic and academic output remains a kind of seething magma that hinders aseptic reflection based on facts rather than on emotions or political or ideological stances. This is a historiographical gap that stems largely from the complicated social and cultural nature of '68; enthusiastic praise contrasts with intentional omissions, and the heterogeneity of motivations based on geographical differences stand out, both in terms of the different uses that the political establishment in power made of the most enlightened outcomes, i.e., granting rights to individuals that had thus far been neglected (Della Porta, 2000). 
However, even if there are no overarching historiographical studies of reference (those that have appeared in the various decades are largely incomplete and ineffective), the strength of penetration of ideas, the ability to change the lives of millions of people, and the major reversals on some issues are easily traceable in the contemporary world, which is the largely unacknowledged offspring of ' 68 . Since ' 68 began to influence ideas and their implementation in everyday life, a revolution in culture and customs has spread. That this was a turning point, from which there would be no going back, is clearly evident from the radically divisive and dissenting attitude that developed towards social behaviours spanning sexual morality, intergenerational relationships, school, family, music and clothing. Blue jeans and rock music became the emblems of a collective way of life shared and put into practice by young people, symbols whose phenomenology was expressed in a different way of dealing with the fossilized society that excluded them (Roszak, 1969; Braunstein and Doyle, 2002).

There is widespread criticism and dispute regarding the hierarchical relationships on which the ruling elite had established a system of co-optation aimed at selfpropagation, thereby marginalizing new subjects who demanded social recognition based on meritocracy, not to mention spaces for dialogue and discussion (Kurz and Tolomelli, 2008). In opposition to this systematic and instrumental metamorphosis of human beings into mere workers' tools, the generations of ' 68 brought to the political stage the desire to explode the contradictions of an oppressive, asphyxiating social system, closed to any possibility of change, in which basic human rights were proclaimed at a formal level but violated and denied in daily life (Fraser et al., 1988).

\section{STUDENTS: A NEW SOCIAL SUBJECT}

The combination of problems and dissatisfaction that were coming to a head in the early 1960s and led, at their peak, to open rebellion and the "great refusal» to live according to the bourgeois canons, resulted in the progressive creation of an alternative culture, a dissenting voice and libertarian paradigm aimed at the demolition of the old, obsolete and rigid behavioural schemes (Cagnolati, 2018; 2019). However, we must ask ourselves what these opposing visions were, and to what extent the head-on collision was foreshadowed by signals that were already widely visible to a careful observer. Elements of a merely material nature had contributed to the formation of an ideology based on strong individualism and personal advancement within the community. In a generation that had experienced hunger, unemployment, indignity and daily deprivation, the subsequent economic miracle strengthened the strong sense of attachment to traditional values (God, homeland and family), along with an awareness of success and money as a measure of self-affirmation. In a society with a rapidly growing population, large sections of 
which had experienced wellbeing and an exponential increase in literacy levels, the younger generations felt alienated from the shared selfish "values», strongly centred around the figure of the white Western male, as if held captive in a labyrinth characterised by a psychological claustrophobia that left no escape. Endogenous phenomena such as the inadequacy of the "fathers» with respect to the needs of "sons», exogenous events of historical origin, and rapid technological advances came together in an explosive synergy whose aim was to shape a new symbolic imaginary, expressed in the music, clothing and alternative lifestyles of the time, which stood in direct opposition to those of the previous generations; indeed, the "fathers» viewed these collective manifestations with alarm and fear, and sought to re-establish control by denigrating their "sons» and then embarking on a vicious campaign of political repression (Caute, 1988).

Why does it seem so important to reconstruct the scope and dimension of the collective imaginary that coalesced around the wave of protests and global rebellion at the hands of young people in ' 68 from educational and historical standpoints? There are clearly many valid reasons. First and foremost, in-depth analysis of the communication mechanisms must refute the desacralizing efforts of the media that gradually forged, with increasing strength and attention, a negative concept of the student-youth binomial. A simplified version of youth was offered to the public, dishevelled and lacking ideals, rooted in the present and destined for certain failure and social marginalisation; each episode was associated with the supposed desire for revolution - an anarchic and nihilistic legend also contaminated by Hollywood cinematography, very fashionable at the time; as examples it is possible to cite The Wild One (1953) and Rebel without a Cause (1955), the last a truly cult movie and global myth that had been spreading among the younger generations since the late 1950s, and later became a folkloric phenomenon and the shared code of a libertarian phenomenology that was well identifiable in the groups of «hippies», "provos» and "teddy boys". This image of youth became the most reliable leitmotif in the press, which did not fail to exploit the possibility of associating episodes of microcriminality (drug use, sexual freedom, running away from home, «hippy encounters») with the concrete protests aimed at radically changing conformist Italian society, which was firmly anchored in the old ways and values (Feuer, 1969, Bongiovanni, 1988).

In reality, however, the most significant development since the early 1960s was a new role for young people that has become visible in other types of agora, not only the spaces traditional linked to protest, usually the workplace, the factory, with its accompanying mythology and inhuman rhythms. Despite the prevailing consumerism, criticism of neo-capitalism-alienating and devoid of any ethical reference, and the vector for a new epidemic of material and moral poverty-began, from the beginning, to re-emerge-like a river flowing underground-in unusual spaces, with a logic different from that of conventional political debate. In the 
vast iconography of the Sixties, physical spaces thus became something different too, and classrooms, corridors, squares and courtyards underwent radical change, aimed not only at breaking down obsolete pedagogical stereotypes, but also building a new educational sociality (Bianca and Gabrielli, 2009). Schools, universities, associations and cultural centres became theatres for a profound metamorphosis; their roles changed as they provided the stage for youth movement protests against their favourite target, the authoritarianism that pervaded the whole of society. Participation in the youth movements with conviction and enthusiasm, as well as constant occupation of the abovementioned spaces, was experienced differently then, reflecting the complexity of the social processes in which young people worldwide were fully immersed.

Even before '68, young people in Italy were a dynamic collective seeking social identity through increasingly extreme and radical forms of political participation, which they saw as an affirmation of their ethical values and universal rights (Della Porta and Tarrow, 1986). In the meandering twists and turns of the youth rebellion, there was a qualitative leap that marked the transition from a loose collective to a fully-fledged protest movement; a profound transformation occurred from generic non-conformism - a new anthropology made of rejection of social conventions, denial of the established order, and opposition to the "values" of the dominant hierarchy-to a more concrete form of protest (Horn, 2007). Social criticism did not take the form of a classist claim within capitalist production relationships, but instead came from the discovery of a false conscience that cloaked democracy in the opulent countries of the West, which held "liberty» up as an absolute paradigm without understanding that individual freedoms were in fact controlled and directed by the powers that be; these influenced every choice, from food to clothing, from thought to behaviour, up to and including definition of the reigning orthodoxy on the formation of human personality. From the very beginning, the spasmodic search for a new subjectivity in open dissent against social conventions, a thousand contradictions notwithstanding, was outlined; it took on the characteristics of the collective mass movement bent on occupying places and claiming them as spaces for communication and anti-authoritarian expression-theatres for dialogue and discussion (D’Eramo, 1978; Bongiovanni, 1988).

\section{BETWEEN FACTS AND OPINIONS}

However, in Italy, university students were part of the vanguard of the struggle for a new world that would see the democratisation and modernisation of education; they were among the most committed to changing the country's social and cultural lifestyles (Hilwig, 2009). They also reflected ways of being in the world and ways of perceiving and understanding it in tune with what was happening on the 
international scene that were far removed from the actions of the previous generation, who had failed to fulfil their promise to expand the margins of freedom and promote the international peace and harmony (Flores and De Bernardi, 1998).

The feature that united all the young people of the student movement was access to education. The very fact that young people had become synonymous with students in the journalistic language and sociological research of that time highlights how profound the modernisation of Italian society-determined by the long expansive cycle of the world economy-was. In fact, this was the first time that this overlap between youth and student roles had occurred; up until the end of the Fifties, education had been almost exclusively the preserve of the social elites, while for most Italian males, being young meant starting work-many as child or illegal labourers-whereas young Italian females were generally housewives-in-training. However, beginning in the Sixties, schooling, in particular the university, underwent a rapid expansion: in 1960-1961 there were 268000 students enrolled in university, and by 1969-1970 there were 642000 . By the end of the decade school and university had become open to "the masses». However, this revolution took place quickly and without orchestration-there was no overarching policy governing the phenomenon, no coordinated plan to reform curricula, reorganise school facilities, or even envisage a national programme of school construction to meet the urgent need for new educational spaces; the entire school system was still identical to that designed by Giovanni Gentile in 1923, at the beginning of the Fascist regime.

The ramifications and consequences of opening the universities to "the masses» were manifold (Breccia, 2013). First and foremost, however, there was a clash of contradictions between the new class of students-from poor families with limited cultural baggage-who were often not fully integrated into the social fabric, and an increasingly closed-minded school system - which had no different paths to offer this new kind of student as they climbed the cultural ladder, and which responded to their difficulties exclusively in terms of expulsion and derision. Furthermore, the social tensions produced by the selection process combined with the problems arising from a dysfunctional labour market, which was incapable of guaranteeing adequate employment for the young people who had been culturally and professionally trained within the expanding school system. Their education could not guarantee the future wellbeing of either themselves or their families. Modernisation without rules or governance thereby fuelled the onset and spread of another type of contradiction: the gap between the knowledge imparted in university courses and the expectations of the learners; this was a cultural rift that affected the entire student body across the board, regardless of the social class of the individual (Chiarante, 1968; Catalano, 1969).

In Italy, many historiographic essays and books have been published in 1968. However, the accurate reconstruction of its origins and events are hampered by a widespread mythopoietic will, which has muddied the waters since the very 
beginning (Rossanda, 1968). Single, specific «newsworthy» episodes were seized upon and hyperbolised by the press and have since had to be retrospectively revisited in the attempt to discern how they fit into a rational and consequential timeline of events (Balestrini and Moroni, 1988). The historic protests of '68 are an enduringly popular topic, and their anniversaries every ten years are inevitably accompanied by numerous celebrations, conferences, workshops, and miscellaneous publications ${ }^{1}$.

This has lent a rather heterogeneous and polymorphic aspect to the published narrative of events, but by looking at the newspapers of the time, which reported on events as they happened, we can begin to get a clearer picture, and discern several prevailing narrative threads. Nevertheless, the desire to piece together the various and scattered tiles of the ' 68 mosaic leads us to construct a somewhat impressionistic picture. Although the overall design is not apparent from the individual pieces, their assembly reveals a striking whole, a key component of the founding myth of the 1960s, which has been, over time, corrupted by a collective imagination eager for heroes and martyrs to the cause of worldwide revolution (for examples we need look no further than Ernesto Che Guevara and Martin Luther King, for their pragmatic ability to mobilise the masses, and Herbert Marcuse and Jean-Paul Sartre for their philosophical input).

In order to better understand the head-on clash that escalated in Italy from the end of 1967, culminating in the dramatic events at the Valle Giulia Architecture Faculty in Rome on $1^{\text {st }}$ May 1968, it is necessary to thoroughly analyse the representation of Italian students in the media during ' 68 , in the belief that this historical event played a fundamental role in both the construction of the specific «student as rebel» icon, and the demonization of young people in general by the part of Italian society that remained conformist and rigidly moralistic. Therefore, rather than a review of political and ideological issues, the focus of this research is the relationship between students, understood as a new social subject that suddenly appeared on the Italian stage, and what I would call the storytelling used by the mass media of the time, the press, which was still largely influenced by a petit bourgeoisie morality and made no effort to understand the real motivations behind the protests and fiercely criticised young people, adopting increasingly crude and violent language in an effort to discredit them. The sources used are taken exclusively from national daily newspapers, namely La Stampa and Stampa Sera whose headquarters were located in Turin, one of the centres of university protest; as a consequence, these sources provide both articles on national news, and a rich vein of local opinion on

${ }^{1}$ To celebrate every tenth anniversary of ' 68 , conferences and numerous volumes have been organized, in particular books by the protagonists of the protests in universities should be noted. In this regard, the case of Mario Capanna, one of the leaders of the revolts against the Catholic University of Milan, for his volumes of autobiographical memories, is emblematic. 
the same events ${ }^{2}$. These articles are analysed, point by point, for both their content (a narration of the facts), and the mechanisms underlying their communication strategy, which, as we will see, aimed to nullify any legitimisation of the student protests, transforming them verbally into elements to be considered highly dangerous for Italian society.

The first outbreaks of rebellion in the busiest university venues occurred as early as the academic year 1967-68, but the newspaper articles seem to underestimate the actual significance of the events to some extent. Indeed, it would not be until January 1968, when the open revolts could no longer be ignored or swept under the rug, that the ruling elite would employ newspapers to carry out a widespread denigration campaign, using language and images to condition public opinion, prompting people to develop a negative assessment of students and their protests, pervaded by a shared and alarmed concern. The strategy is widely and clearly evident: it was a question of emphasising the students' anger, combativeness and challenges to the social order to create the feeling that these were not isolated events but that a real revolution had begun that would undermine the power of the preceding generations.

The research hinges on the revolt by students at the University of Turin, and the various stages of the rebellion are analysed using the articles. As is often the case, the long-fermented protests regarding education, the internal life of the University, the out-dated lessons, classroom overcrowding and the examinations conducted by the professors as if they were interrogations exploded due to contingent circumstances; the cycle of occupations of the humanities faculty campus in Turin began on $27^{\text {th }}$ November 1967, following a mobilisation that had begun the previous week in protest against a measure concerning university buildings ${ }^{3}$. During the University Board meeting, the rector, Mario Allara, proposed purchasing an area on the outskirts of the city with a view to significantly expanding the university's footprint ${ }^{4}$. This work was deemed necessary as a result of the sharp increase in enrolment, which had also affected the University of Piedmont. The university students agitated and objected that the relocation that would follow would cause serious damage to university life, in the belief that the buildings in which the faculties were housed

2 The articles used for the research are selected from La Stampa, a national newspaper, which represents the ideas of the capitalist bourgeoisie of Turin, and Stampa Sera, the supplement that is published every two days with news and insights, especially on events of local interest.

${ }^{3}$ The increase in the number of enrolments required a global re-evaluation of the capacity of the buildings that were to host lessons at the university of Turin. However, each of the various solutions approved by the academic Senate were rejected by the students.

${ }^{4}$ From November 1967 a group of students protested against the project approved on 22 November 1967 by the University's administrative board; the project involved moving several faculties to Venaria Reale, within La Mandria park and away from the city centre. 
should remain in the centre of Turin, both for easier access and due to the numerous services enjoyed by students (De Luna, 1991).

However, from the reconstructions of the episodes of rebellion provided by their major players and witnesses, it becomes clear that this issue was only a pretext. Peppino Ortoleva, one of the leaders of the ' 68 revolt in Turin, confirmed that "even then we were well aware of the greater breadth, and the long-term nature of the struggle; there was also contact with other universities, which would begin agitating more or less at the same time, on more general issues such as the fight against the Gui plan and an actual structural change in the university» (Avondo, 2018). The students were set on protesting against the teaching methods and intended to block the start of the courses for the academic year 1967-68, organising a closed-door occupation of the iconic building of Palazzo Campana ${ }^{5}$ (Ferraris, 1993).

This first phase of the dispute was marked by the desire to completely break up the traditional hierarchy; various episodes testify to verbal violence against the lecturers, considered the main culprits of the situation that had arisen within the university. The old-fashioned structure failed to meet the new demands in terms of both student numbers and curricula content; in order to clarify their objectives in this regard, the students formulated a declaration, the Carta rivendicativa, in which they set out their claims explicitly; they called for the dismantling of the basic pillars of the university management, from courses to tests-a change that would deprive the lecturers of their monopoly on the instruments of their power, i.e. lectures and examinations ${ }^{6}$.

The result was a verbal confrontation between the rebellious students-who no longer recognised the representative functions of the traditional bodies, now stripped of their consensus-and the rector himself, who was determined not to listen to their demands. In the months that followed, however, the decision was made to adopt more aggressive methods on both sides: students stormed and occupied the university buildings, and the rector more and more often called upon the police to intervene, and denounced those who had carried out destructive actions, even going so far as to haul before the courts 488 students deemed guilty of obstructing the regular conduct of the lessons and insulting and threatening their lecturers. This highly volatile climate was compounded by the news coming from the other university campuses, thereby giving the feeling of a revolt now in full swing on the national stage. The clashes culminated in Turin in March and May 1968, when the episodes became more and more bloody, and the protests spilled

${ }^{5}$ The prestigious building was built in the centre of Turin in the late 17th century. From 1967 to 1970, it was the centre of the Turin Student Movement and was occupied several times by students.

${ }^{6}$ Carta rivendicativa degli studenti, in Movimento Studentesco (Ed.), Documenti della rivolta universitaria, Laterza, Bari, 1968. Some extracts in La Stampa (1968), "Ecco la "carta rivendicativa" degli studenti universitari», 20 January, p. 2. 
out of the campuses and onto the streets and town squares. The student rebellion was now in full view, having broken the bounds of the purely academic sphere to play a role in the global protest against a political system that failed to take seriously the motivations and criticism of young people, continuing to systematically exclude them from any political planning. The clash between students and teachers turned into a stark contrast between the new generation and the old hegemonic class in power (Kurz, 1999).

\section{THE REVOLT IN THE ARTICLES OF LA STAMPA AND STAMPA SERA: AN ANALYSIS OF TRENDS}

If we consider the news articles that explicitly dealt with the issues of university revolt and students in the time frame from $1^{\text {st }}$ January 1968 to $30^{\text {th }}$ June 1968 , there were a surprising number published-281 articles in La Stampa and 121 in Stampa Sera ${ }^{7}$. In the first phase of the research, we selected and quantified the articles numerically, further subdividing them on local, national and international levels. The second phase of the analysis was focussed on the content, in order to reconstruct the narrative of the student protests that intentionally emerges from the pages of the newspaper.

The attention of the journalists ${ }^{8}$ was predominantly focussed on local occurrences, but never failed to put these in the context of the events that were taking place at the national level (e.g., the riots and clashes at the University of Rome, which were given a lot of column inches) as well as political or ideological ideas being put forward worldwide. Analysis of the articles reveals some clear trends, precise directives that guided communication in order to direct public opinion and ensure that the image of the student that was being shaped would be negative and problematic, and that their claims would be considered as nothing more than fads or whims by any children of the wealthy bourgeoisie who might have been inclined to imitate their companions at the head of the contemporary uprisings in American and German universities.

So, let us review the fundamental points that emerge from the research in order. One of the first facts to be noted concerns the content of the articles, which took on increasingly alarmist and worried tones as the protests in Turin went on, with attitudes becoming more radical and violent; beginning in March 1968, the emphasis on both the headlines and the content of the articles focussed on describ-

7 The number of articles closely follows the escalation of the protests. For a more precise idea, see tables 1-4, which show the numerical data pertaining to the articles in La Stampa and Stampa Sera, both globally (for the period January-June 1968) and for different levels.

8 The overwhelming majority of articles only provide information on the facts and do not report the journalists' names, unlike the opinion pieces or interviews with important figures in the academic world, which always bore the names of nationally renowned journalists. 
ing the unrest caused by students, and the frequent interventions of the police to clear the buildings being occupied by the protesters. There was repeated emphasis of the overt nature of the challenge to the academic authorities being mounted by the most prominent students, such as Guido Viale and Luigi Bobbio, who were considered and acknowledged as leaders of the Turin student movement in all respects. The lexicon used in the headlines reflects a desire to alarm readers and cast a negative light on the activities of the young people and their destructive behaviour.

Secondly, in order to support the criticism and demonization of the student universe, there was ample space given to the voices of the authorities, i.e., the many published interviews, letters and opinion pieces by the rectors, faculty deans and esteemed and well-known professors in the academic community. The voice of the establishment served to further legitimise scaremongering and created even more distance from the demands of the students, which were considered absurd and implausible, in particular the calls to modernise the fossilized university world, to reject the way in which it was perpetuated in lectures, and the perception that the students themselves were reduced to non-entities, mere numbers, during exams.

Another visible trend concerns the area that may be defined as a «judicial chronicle»; there were frequent reports providing detailed information on the trials and incarceration of students, the punishments imposed for rioting, the damage to buildings and the offenses against teachers. This news, however, became more ambiguous - the more the episodes multiplied, the more the media tended to assign the students involved the role of martyrs and victims of an unjust system that condemned them rather than listening to their complaints.

In the pages of the newspapers, a further chain of clues is provided by analysis of the news being reported from the other university campuses; on $1^{\text {st }}$ March 1968, an entire inner page of La Stampa was dedicated to the events of Rome, Florence, Venice and Trento, emphasising the now national scale of the student revolt, and the disruptive force of the protest that had even begun to infect middle school students, who were organising their own school sit-ins. The episodes and clashes were reported as if to give the impression of a dangerous spreading epidemic, culminating in the most politically significant episode: the events at Valle Giulia of $1^{\text {st }}$ June 1968, which were narrated in a language closely reminiscent of a war diary9.

Finally, it should be remembered that at the same time the Italian Parliament was debating the Gui law ${ }^{10}$, which was aimed at completely overhauling the entire

9 The battle of Valle Giulia (March 1, 1968) is the name given to a street clash between university students and the police arising from demonstrations held by the ' 68 student movement. The University of Rome Faculty of Architecture was at the centre of the clashes.

${ }^{10}$ The Gui law, named after the minister of public education, Luigi Gui, was discussed in the Italian Parliament in December 1967 and March 1968, but never came to be approved because the government resigned, and new elections were called. The law aimed to significantly reduce the autonomy of universities and to solve the problems concerning the recruitment of teachers. 
university structure, and could, perhaps, if approved, have put an end to the demonstrations. In reality, however, the story had a very different ending-because of the political crisis in question, the government presided over by Aldo Moro stood down and new elections were called; the law was never passed and was not even discussed in the following legislative session, which began on $25^{\text {th }}$ June 1968.

\section{CONCLUDING REFLECTIONS}

In light of the articles analysed, it is possible to delineate several considerations regarding the value and peculiarity of the local press as a source for historical analysis of the university in '68. The first element to be reiterated concerns the "direct» documentary value of the texts examined, which contain a significant amount of information, data and multiple other historical references. In addition, it may be interesting to report the value of a specific genre of commentary dedicated to the criminal trials, held following deflagration of the dispute. The lawyers' arguments and prosecutors' closing statements (often reported in newspaper columns) also contain analyses and assessments relating to the youth movements and their motivations.

However, the press is not a wholly impersonal source, and qualifies as a not entirely aseptic and passive lens on the events that it reported upon. Indeed, newspapers begin to be privileged interlocutors of the protagonists themselves: academic authorities, leaders and student groups systematically adopted the press release as a communication tool, not to mention the various types of documents and motions-as well as academic Senate decisions - that regularly appeared in the pages of the newspapers.

The tendency to prefer the arguments of teachers, rectors and «moderate» students fuelled a progressive conflict with the student movement, which would soon coin the term "bourgeois press» and openly criticise the mainstream news media, eventually developing their own «alternative» communication systems (Fadda, 2009).

The newspapers could hardly have done otherwise, due to their explicit purpose of spreading and amplifying many political, cultural, social and conventional references, which would sow the seeds of the revolt and enshrine its key words. Despite the polemical and disparaging linguistic register they unfailingly resorted to, however, there was a constant focus on the anti-colonial struggles, the Vietnam War, Third-Worldist campaigns, the hippies, new philosophical currents and mass phenomena. Nevertheless, a certain delay in understanding the epochal extent of student unrest is apparent; they continued to grant significantly more space to the positions of the academic authorities and teachers who defended traditional values, rather than to the students' motives (Crainz, 2003).

As for the huge amount of articles published in La Stampa and Stampa Sera, these confirm the hypothesis that the Turin elite and newspaper owners were paying 
close attention to the students' open rebellion, which they seem to have viewed as a challenge to the traditional bourgeois values of decorum, success and co-optation among the ranks of professional service providers. They intentionally painted a negative, diabolical picture of the student, whose primary goal was to criticise, demolish and fragment, rather than aspiring to their proper place in productive society. The division was entirely radicalised: on the one hand there were those who governed the universities, fearful of losing their tyrannical power and privileges, and on the other a generation who studied and experienced their present and future roles in a manner totally opposed to their forebears and the authorities' expectations. The battle was fought with each of the university campuses involved using different strategies, but apparently united behind a common goal: to make the university, considered out-dated and obsolete, a more efficient structure, more suitable for the modernised world.

In the articles, it is rare to discern hints of a desire to understand the true causes of the protests. There were no in-depth investigations into the role played by the liberalisation of access to university courses, for example, and no attempts to highlight the structural flaws, the paucity of teaching and residential facilities-all the problems that were making the lives of university students so difficult. One thing that does emerge, however, is the purposeful boycott of the very concept of mass university education, placing so many obstacles in the path of those from humble or socially disadvantaged backgrounds, who were technically granted access to but were soon expelled by a system that still privileged the wealth, cultural landmarks and social affiliation of the children of the bourgeoisie.

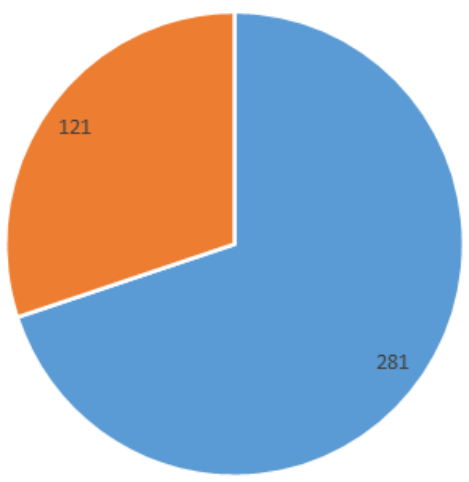

- La Stampa = Stampa Sera

Table 1. Total numbers of articles related to the student protests

[International, national and local level]

1st January 1968-30th June 1968

Source: La Stampa, Stampa Sera

(Data collected by the author) 


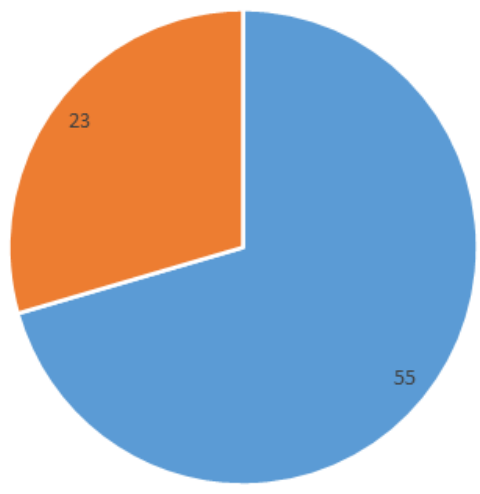

- La Stampa = Stampa Sera

Table 2. Total numbers of articles related to the student protests [International level]

1st January 1968-30th June 1968

Source: La Stampa, Stampa Sera

(Data collected by the author)

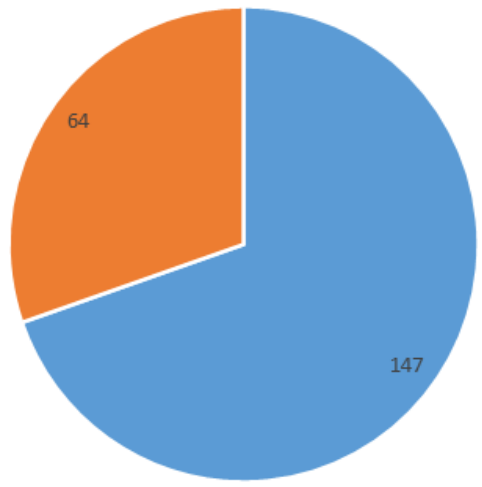

- La Stampa = Stampa Sera

Table 3. Total numbers of articles related to the student protests [National level: Italy]

1st January 1968-30th June 1968

Source: La Stampa, Stampa Sera

(Data collected by the author) 


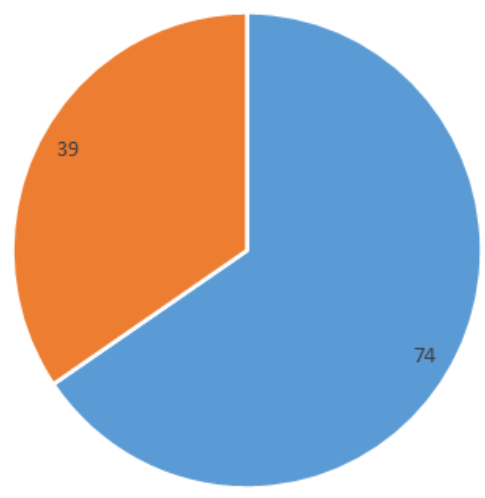

- La Stampa = Stampa Sera

Table 4. Total numbers of articles related to the student protests [Local level: Turin] 1st January 1968-30th June 1968 Source: La Stampa, Stampa Sera (Data collected by the author)

\section{BIBLIOGRAPHY}

\subsection{Articles}

La Stampa (1968). «Cosa vogliono gli studenti?», January 3, p. 2.

La Stampa (1968). «Azione disciplinare all'Università», January 5, p. 2.

Stampa sera (1968). "Allara: "È nostro dovere ristabilire la disciplina"», January 5-6, p. 2.

La Stampa (1968). «Università: e gli studi?», January 6, p. 2.

La Stampa (1968). "Mercoledì c'è lezione all'Università 80 studenti annunciano: «Occuperemo»», January 7, p. 2.

La Stampa (1968). «Disordini all'Università», January 11, p. 2.

La Stampa (1968). «Le lezioni a Palazzo Campana bloccate dagli studenti», January 12 , p. 2. 
Stampa sera (1968). "A Palazzo Campana riprendono le lezioni in un clima inquieto», January 12-13, p. 2.

La Stampa (1968). «ll monito del Senato accademico contro le violenze studentesche», January 14, p. 2.

La Stampa (1968). "Ancora un corteo e chiassate in centro. Primo accordo fra rettore e studenti», January 18, p. 6

La Stampa (1968). «Ecco la "carta rivendicativa» degli studenti universitari», January 20, p. 2.

La Stampa (1968). «Confusa assemblea all'Università», January 21, p. 2.

La Stampa (1968). "Chiuse a tempo indeterminato le facoltà di Palazzo Campana», January 23, p. 2.

La Stampa (1968). "L'azione di disturbo degli studenti si estende alle facoltà scientifiche», January 27, p. 2.

Stampa Sera (1968). «Dal magistrato i protagonisti dell'occupazione all'Università», February 5-6, p. 2.

La Stampa (1968). «Che cosa chiedono gli studenti «ribelli» dell'Ateneo di Torino», February 6, p. 7.

Stampa sera (1968). "Sgomberata l'Università per paura di un'altra bomba», February 16-17, p. 1.

La Stampa (1968). "Una zuffa fra gli studenti pro o contro l'occupazione», February 20, p. 2.

La Stampa (1968). «Esami sospesi alla Facoltà di lettere. Una caotica assemblea degli studenti», February 21, p. 2.

La Stampa (1968). "138 studenti di Architettura votano una nuova occupazione della Facoltà», February 24, p. 2.

La Stampa (1968). "Ordigno scoppia presso la casa del rettore dell'ateneo di Torino», February 27, p. 5. 
La Stampa (1968). «Occupato Palazzo Campana», March 1, p. 2.

La Stampa (1968). «Niente legge per gli atenei», March 10, p. 15.

La Stampa (1968). «Le ondate di malcontento nelle nostre Università», March 14, p. 3.

La Stampa (1968). "Una polemica in Consiglio sugli studenti denunciati», March 14, p. 2.

La Stampa (1968). «Professori di Architettura favorevoli ad annullare I'anno accademico?», March 22, p. 2.

La Stampa (1968). «La crisi dell'Università», March 23, p. 1.

La Stampa (1968). «La situazione nelle Università», April 6, p. 17.

La Stampa (1968). "Le condizioni dell'Università per trattare con gli studenti», April 9, p. 2.

La Stampa (1968). «Gli studenti presenteranno ai presidi nuove rivendicazioni per le trattative», April 10, p. 2.

La Stampa (1968). «In nove punti la risposta del Senato accademico agli studenti universitari», April 20, p. 2.

La Stampa (1968). «Punti fermi all'Università», April 21, p. 5.

La Stampa (1968). «A Palazzo Campana le lezioni riprese e subito interrotte», April 23, p. 4.

La Stampa (1968). «ll Senato accademico ha deciso la chiusura di Palazzo Campana», April 24, p. 2.

La Stampa (1968). «Corteo di tremila studenti e occupazione simbolica del nuovo palazzo universitario», April 25, p. 2.

La Stampa (1968). "Studenti chiedono al Rettore di riaprire Palazzo Campana», April 27, p. 2.

La Stampa (1968). «Tafferugli tra gli studenti in un'assemblea a Chimica», April 30, p. 4. 
La Stampa (1968). «Si è fatto ben poco a Torino per la sede dell'Università», May 4, p. 9.

La Stampa (1968). «Ritorna all'esame dei professori la riapertura di Palazzo Campana», May 7, p. 4.

La Stampa (1968) "Violente discussioni a Magistero tra studenti moderati e professori», May 9, p. 2.

La Stampa (1968). «I professori fissano la data per riaprire Palazzo Campana», May 16, p. 2.

La Stampa (1968) «La riforma dell'Università alle camere prima dell'estate», May 19, p. 1.

La Stampa (1968). «Inquieta pace a Palazzo Campana. Nuove richieste degli studenti», May 31, p. 2.

La Stampa (1968). «Le modifiche attuate all'università sono soltanto un inizio di riforma», June 1, p. 2.

La Stampa (1968). «Scontri all'Ateneo di Roma», June 2, p. 9.

La Stampa (1968). «A Roma la polizia sgombera I'Ateneo», June 4, p. 9.

La Stampa (1968). «Studenti moderati e filocinesi si scontrano a Palazzo Campana», June 4, p. 2.

La Stampa (1968). «A Milano 2 mila studenti scatenano violenti disordini per tutta la notte», June 9, p. 4.

La Stampa (1968). «Tre arresti a Milano nell'ateneo di Stato», June 12, p. 18.

La Stampa (1968). "La battaglia degli studenti nei paesi comunisti europei», June 14 , p. 5.

La Stampa (1968). «L'Università aspetta la riforma tra caos, esperimenti e speranze», June 21, p. 3.

La Stampa (1968). «Cosa chiedono gli assistenti per la riforma dell’Università», June 28, p. 4. 
La Stampa (1968). "Nell'Università troppi studenti affidati ad un solo professore», June 30, p. 4.

\subsection{References}

Artières, P. \& Zancarini-Fournel, M. (dirs.). (2008). 68. Une histoire collective (19621981). Paris: La Découverte.

Avondo, G. V. (2018). I/ '68 a Torino. Torino: Edizioni del Capricorno.

Balestrini, N. \& Primo, M. (cur.). (1988). L'orda d’oro. Milano: SugarCo.

Bianca, M. L. \& Gabrielli, P. (cur.). (2009). I linguaggi del’ 68. Milano: FrancoAngeli.

Billi, F. (cur.). (2001). Gli anni della rivolta. 1960-1980: prima, durante e dopo il '68. Milano: Punto Rosso.

Boccia, Pietro. (1988). Giovani allo specchio: il '68 rivoluzione o modernizzazione? Roma: Ripostes.

Bongiovanni, B. (1988). Società di massa, mondo giovanile e crisi di valori. La contestazione del '68. In N. Tranfaglia \& M. Firpo (dir.), La storia. I grandi problemi dal Medioevo all'Età Contemporanea, vol. VII, L'Età Contemporanea (t. 2, La cultura, pp. 671-694). Torino: UTET.

Brambilla, M. (1994). Dieci anni di illusioni. Storia del Sessantotto. Milano: Rizzoli.

Braunstein, P. \& Doyle, M. W. (ed.) (2002). Imagine Nation. The American Counterculture of 1960 s and 70s. New York and London: Routledge.

Breccia, A. (cur.). (2013). Le istituzioni universitarie e il Sessantotto. Bologna: Clueb.

Cagnolati, A. (2011). Ma che colpa abbiamo noi? Mass-media e protesta studentesca. In C. Betti \& F. Cambi (cur.), II '68: una rivoluzione culturale tra pedagogia e scuola (pp. 187-193). Milano: Unicopli.

Cagnolati, A. (2018). Los jóvenes universitarios y la opinión pública en Italia durante el '68. Historia da Educação, 22(54), pp. 29-46. https://doi.org/10.1590/2236$3459 / 76897$ 
Cagnolati, A. (2019). Tra mitopoietica e ribellione. Giovani, formazione e controcultura negli anni Sessanta. In E. Madrussan (cur.), Crisi della cultura e coscienza pedagogica. Per Antonio Erbetta (pp. 39-48). Como-Pavia: Ibis.

Cagnolati, A., Hernández Huerta, J. L. \& and Payà Rico, A. (ed.). (2019). «The Sixties Reloaded. Exploring social movements, student protests and youth rebellion", Espacio, Tiempo y Educación 6(1), pp. 1-159. https://doi.org/10.14516/ete.280

Cagnolati, A. \& Hernández Huerta, J. L. (2020). Rebeldes y protagonistas. Una investigación comparativa sobre los estudiantes y el 68 en Italia y Brasil. In T. Pironi (cur.), Autorità in crisi. Scuola, famiglia e società prima e dopo il '68 (pp. 145-158). Canterano (Roma): Aracne editrice.

Carey, E. (ed.), (2016). Protests in the Streets: 1968 across the Globe. Indianapolis: Hackett Publishing.

Catalano, F. (1969). I movimenti studenteschi e la scuola in Italia (1938-1968). Milano: Il Saggiatore.

Caute, D. (1988). Sixty-Eight. The Year of the Barricades. London: Hamish Hamilton.

Chiarante, G. (1968). La rivolta degli studenti. Roma: Editori Riuniti.

Coccia, B. (cur.). (2008). 40 anni dopo: il Sessantotto in Italia fra storia, società e cultura. Roma: APES.

Crainz, G. (2003). L'anno e gli anni degli studenti. In G. Crainz, Il paese mancato: dal miracolo economico agli anni Ottanta (pp. 217-293). Roma: Donzelli.

D'Eramo M. (cur.). (1978). L'immaginazione senza potere: mito e realtà del '68. Roma: Mondo operaio-Avanti.

De Luna, G. (1991). Aspetti del movimento del '68 a Torino. In A. Agosti, L. Passerini \& N. Tranfaglia (eds.), La cultura e i luoghi del'68 (pp. 190-211). Milano: Angeli.

Della Porta, D. (2000). Le mouvement étudiant et l'État en Italie: l'escalade de la violence. In G. Dreyfus-Armand, R. Franck, M.-F. Lévy \& M. Zancarini-Fournel (dirs.), Les Annés 68. Le temps de la contestation (pp. 423-441). Brussels: Complexe. 
Della Porta, D. \& Tarrow, S. G. (1986). Unwanted Children. Political Violence and the Cycle of Protest in Italy. 1966-1973. European Journal of Political Research, 14, pp. 607-623. https://doi.org/10.1111/j.1475-6765.1986.tb00852.x

Fadda, E. (June 2009). La politica di comunicazione del movimento studentesco del '68: il caso di Torino. II presente e la storia, 75, pp. 45-76.

Ferraris, P. (1993). Sulla comunità studentesca di Palazzo Campana. Parolechiave, 1, pp. 149-168.

Feuer, L. S. (1969). The Conflict of Generations: The Character and Significance of Students Movements. New York: Basic Books.

Flores, M. \& De Bernardi. A. (1998). II Sessantotto. Bologna: il Mulino.

Fraser Ronald, D. B. \& Eynon, B. (eds.). (1988). 1968: A Student Generation in Revolt. New York: Pantheon Books.

Gitlin, T. (1987). The Sixties: Years of Hope, Days of Rage. Toronto and New York: Bantam Books.

Hilwig, S. J. (2009). Italy and 1968: Youthful Unrest and Democratic Culture. Basingstoke: Palgrave Macmillan. https://doi.org/10.1057/9780230246928

Horn, G.-R. (2007). The Spirit of '68: Rebellion in Western Europe and North America, 1956-1976. Oxford: Oxford University Press.

Kurlansky, M. (2004). 1968. The Year That Rocked the World. New York: Ballantine.

Kurz, J. (1999). Verso la contestazione globale. La primavera calda del movimento studentesco italiano. Novecento, 1, pp. 55-69.

Kurz, J. \& Tolomelli, M. (2008). Italy. In J. Martin Klimke \& J. Scharloth (eds.), 1968 in Europe. A History of Protest and Activism, 1956-1977 (pp. 83-96). New York: Palgrave Macmillan. https://doi.org/10.1057/9780230611900_8

Marino, G. C. (2004). Biografia del Sessantotto: utopie, conquiste, sbandamenti. Milano: Bompiani.

Marwick, A. (1998). The Sixties: Cultural Revolution in Britain, France, Italy, and the United States, c. 1958-c. 1974. Oxford and New York: Oxford University Press. 
Marwick, A. (2005). The Cultural Revolution of the Long Sixties: Voices of Reaction, Protest, and Permeation. The International History Review, 27(4), pp. 780-806. https://doi.org/10.1080/07075332.2005.9641080

Ortoleva, P. (1988). Saggio sui movimenti del '68 in Europa e in America. Roma: Editori Riuniti.

Packard, V. (1957). The Hidden Persuaders. New York: McKay.

Payà Rico, A., Hernández Huerta, J. L., Cagnolati, A., González Gómez, S. \& Valero Gómez, S. (eds.). (2018). Globalizing the student rebellion in the long '68. Salamanca: FahrenHouse.

Revelli, M.. (1991). II '68 a Torino. Gli esordi: la comunità studentesca di Palazzo Campana. In A. Agosti, L. Passerini \& N. Tranfaglia (eds.), La cultura e i luoghi del '68 (pp. 216-266). Milano: Angeli.

Ross, K. (2002). May '68 and Its Afterlives. Chicago: The University of Chicago Press. https://doi.org/10.7208/chicago/9780226728001.001.0001

Rossanda, R. (1968). L'anno degli studenti. Bari: De Donato.

Rostagno, M. (cur.). (1968). Università: l'ipotesi rivoluzionaria. Padova: Marsilio.

Roszak, Th. (1969). The Making of a Counter Culture. Berkeley: University of California Press.

Ruggiero, G. (1970). Maggio e dopo: motivi e problemi della contestazione giovanile. Milano: Mursia.

Tarrow, S. G. (1989). Democracy and disorder: protest and politics in Italy, 1965-1975. Oxford: Clarendon Press.

Tolomelli, M. (2008). Il Sessantotto. Una breve storia. Roma: Carocci.

Touraine, A. (1968). Le mouvement de mai ou le communisme utopique. Paris: Editions du Seuil.

Viale, G. (1978). Il Sessantotto. Tra rivoluzione e restaurazione. Milano: Mazzotta. 